\title{
FUNGSI GENDING AYAK WOLU PADA WAYANG KULIT GAGRAG JAWA TIMURAN KI SURWEDI
}

\author{
Jepri Ristiono \\ Karyawan di Bentara Budaya Surakarta \\ dapat dihubungi di cibok87@gmail.com | 085725073326
}

\begin{abstract}
ABSTARCT
This article originated from the interest of the author when he saw the phenomenon that occurred in the East Javanese leather puppet show Ki Surwedi, especially gending Ayak pathet Wolu which is very dominating. The discussion is focused on the gending function of Ayak pathet Wolu which concerns the relation of the song with the gamelan, so that it can conclude about the role and function of the song. Therefore, this article is qualitative with priority on the form of interview data and literature, and presented in descriptive-analytic. The data collected from various sources was analyzed using the function theory initiated by Alan P. Merriam in a book entitled The Anthropology of Music, translated by Hajizar in the form of "Concept as Source of Analysis". From this research, it can be concluded that the gending function of Ayak pathet Wolu in wayang Ki Surwedi is one of the art forms from ancestors that has been passed down from generation to generation. Therefore, it has become our collective duty to preserve it in order to avoid extinction.
\end{abstract}

Kata kunci: ayak wolu, fungsi gendhing, wayang Jawa Timuran, Ki Surwedi

\section{Pathet dalam Wayang Kulit Gagrag Jawa Timuran}

Perkembangan seni pertunjukan wayang kulit telah jauh dimulai sejak berabad-abad yang lalu', sehingga dapat dikatakan bahwa seni wayang kulit yang berkembang di Nusantara merupakan bagian penting dari sejarah bangsa Indonesia.
Keanekaragaman bentuk pakeliran wayang kulit yang ada di Indonesia dapat dipahami sebagai sebuah upaya pemetaan yang disepakati oleh para seniman saja. Hasil dari pemetaan tersebut dikenal oleh para seniman/dalang dengan istilah gaya atau gagrag. Menurut Ki Surwedi, memahami gagrag dan gaya lebih identik dengan ciri khas yang kemunculannya

\footnotetext{
${ }^{1}$ Umar Kayam mengindikasikan bahwa wayang kulit di Jawa diperkirakan sudah ada sejak abad X M. (Kelir Tanpa Batas, Hal. 4)
} 
banyak dipengaruhi dan disepakati oleh masyarakat pendukung kebudayaan tersebut. Bila kita membicarakan tentang wayang kulit dalam lingkup nasional, maka ada istilah gaya Jawa Tengahan, Yogyakarta, Banyumasan, Bali, atau Jawa Timuran. Sedangkan, jika berbicara tentang wayang kulit dalam lingkup Jawa Timuran, maka akan ditemui gaya Porongan, Majakertan/Trowulanan, serta Lamongan. Ki Surwedi sendiri adalah seorang dalang wayang kulit Jawa Timuran gagrag Porongan.

Pada umumnya, ciri khas dari masing-masing gagrag wayang kulit dapat kita cermati dari segi pendukung pakeliran, salah satunya adalah pada iringan gamelan yang digunakan. Dari segi karawitan, pagelaran wayang kulit biasa dibagi atas beberapa pathet. Pada pakeliran wayang kulit di Jawa Tengah, lazimnya dikenal tiga pathet, yaitu pathet Nem (6), pathet Sanga (9), dan pathet Manyura. Di Yogyakarta, istilah pathet memiliki kesamaan dengan istilah di Jawa Tengah, tetapi jumlah totalnya ada empat, dengan tambahan pathet Galong. Dalam wayang kulit gagrag Jawa Timuran sendiri, dikenal empat jenis pathet, yakni pathet Sepuluh (10), pathet Wolu (8), pathet Sanga (9), dan pathet Serang. Urutan pathet dalam pagelaran wayang Jawatimuran dapat dilihat pada tabel berikut.

\begin{tabular}{|c|c|c|c|}
\hline Pathet & Keterangan & Repertoar & Waktu \\
\hline Sepuluh & $\begin{array}{l}\text { Diawali dengan pathet } \\
\text { Sepuluh pada adegan jejer } \\
\text { sepisan. Peralihan pathet } \\
\text { dari Sepuluh ke Wolu di- } \\
\text { tandai adanya sendhon. }\end{array}$ & Jejer sepisan; gendhing Gandakusuma. & $\begin{array}{c}22.00 \\
\text { s.d. } \\
23.00\end{array}$ \\
\hline Wolu & $\begin{array}{l}\text { Pada jejer sepisan terdapat } \\
\text { janturan. Setelah janturan, } \\
\text { iringan sudah berganti } \\
\text { menjadi pathet Wolu. } \\
\text { Pada pathet ini terdapat } \\
\text { adegan kedha-ton, adegan } \\
\text { paseban jawi, adegan jejer }\end{array}$ & $\begin{array}{l}\text { - Kedhatonan; gendhing Gedhog Rancak, } \\
\text { Celeng Mogok, Daru Maya, Gagak Setra. } \\
\text { - Paseban jawi; gendhing Ayak kempul } \\
\text { arang (getekan), Krucilan. } \\
\text { - Jejer kedua; gendhing Mongrang. } \\
\text { - Prang sepisan; gendhing Ayak pancer } 5 \\
\text { untuk tokoh wayang gagahan, pancer } 2\end{array}$ & $\begin{array}{c}23.00 \\
\text { s.d. } \\
02.00\end{array}$ \\
\hline
\end{tabular}




\begin{tabular}{|c|c|c|c|}
\hline & $\begin{array}{l}\text { kedua, prang sepisan, } \\
\text { sertajejer ketiga. }\end{array}$ & $\begin{array}{l}\text { untuk tokohwayangalusan. } \\
\text { - Jejer ketiga; gendhing Dhudha } \\
\text { Bingung. }\end{array}$ & \\
\hline Sanga & $\begin{array}{l}\text { Gendhing berganti } \\
\text { pathet Sanga pada } \\
\text { pertengahan jejer ketiga, } \\
\text { ditandai dengan adanya } \\
\text { janturan. Dalam pathet ini } \\
\text { terdapat adegan prang } \\
\text { gagal, jejer keempat, jejer } \\
\text { kelima. }\end{array}$ & $\begin{array}{l}\text { - Prang gagal; gendhing Ayak kempul } \\
\text { kerep. } \\
\text { - Jejerkeempat; gendhing Jonjang. }\end{array}$ & $\begin{array}{c}02.00 \\
\text { s.d. } \\
03.45\end{array}$ \\
\hline Serang & $\begin{array}{l}\text { Gendhing berganti pathet } \\
\text { Serang pada pertengahan } \\
\text { jejer kelima, ditandai } \\
\text { dengan janturan. Dalam } \\
\text { pathet ini terdapat adeg- } \\
\text { an prang brubuh dan } \\
\text { tancepkayon. }\end{array}$ & $\begin{array}{l}\text { - Jejer kelima; gendhing Rangsang. } \\
\text { - Prang brubuh; gendhing Krucil kempul } \\
\text { kerep. } \\
\text { - Tancep kayon; gendhing penutup. }\end{array}$ & $\begin{array}{c}03.45 \\
\text { s.d. } \\
04.15\end{array}$ \\
\hline
\end{tabular}

Struktur atau urutan data sajian pakeliran wayang kulit di atas merupakan pakem yang umum disepakati oleh masyarakat pedalangan Jawa Timuran. Dalam pementasannya, bisa dikatakan $\mathrm{Ki}$ Surwedi sangat percaya pada daya hidup gayanya sendiri, dengan tradisi yang diwarisi dan dilestarikannya (Umar Kayam, 2001: 221). Selain itu, pakeliran wayang kulit Ki Surwedi juga bisa dikatakan masih memegang makna tradisi dalam pertunjukan nya. Belum banyak sentuhan kreativitas yang bersifat modern. Surwedi sendiri bukan mau menolak suatu tawaran yang menarik untuk membuat dirinya populer dan banyak ditanggap, namun dia sendiri yang memilih untuk meneruskan gayanya, yakni gaya Porongan yang pernah diajarkan oleh gurunya, Ki Sulaiman. Selain belajar di tempat Ki Sulaiman, Surwedi memiliki pandangan berbeda tentang bagaimana cara membangun kreativitas dalam mendalang. Surwedi sendiri bisa dikatakan memiliki kreativitas yang berbeda dengan dalang- 
dalang Jawatimuran lain, yang kreativitas menggarap pakelirannya cenderung hanya pada bentuk visual pakeliran, serta condong pada gendhing yang diminati masyarakat pecinta pedalangan.

\section{Kedudukan Gendhing Ayak dalam Wayang Kulit Gagrag Jawa Timuran}

Gendhing merupakan sebutan bentuk karya musik tradisional yang diberikan kepada suatu bentuk/corak lagu, yang pengungkapannya selalu berhubungan erat dengan instrumen gamelan. Dalam perwujudannya, gendhing merupakan rangkaian nada-nada instrumen yang telah disusun dengan kesepakatan tertentu, dan bentuk di sini yaitu bentuk konvensional yang cirinya dapat diidentifikasi melalui instrumen struktural seperti; gong, kempul, kenong, kethuk, dan jumlah sabetan gamelan (Joko Purwanto, 2004:69).

Setiap gendhing selalu memiliki peranan yang digunakan sesuai dengan adegan-adegan yang disajikan. Dalam dunia pewayangan Jawa Timuran, gendhing Ayak merupakan satu elemen penting yang kehadirannya tidak dapat ditiadakan. Gendhing Ayak memiliki empat macam bentuk, hal ini didasarkan pada penggolongan pathet (Wolu, Sanga, Serang, dan Sepuluh). Gending Ayak memiliki dua variasi garap, yakni garap kempul kerep dan kempul arang.
Secara sederhana, pengertian garap kempul kerep ditandai dengan pola pukulan kempul yang lebih rapat. Sebaliknya, garap kempul arang ditandai dengan pukulan kempul yang relatif jarang (dua kali lebih jarang dibanding kempul kerep). Untuk memudahkan pemahaman terkait hal tersebut, berikut adalah ilustrasinya.

\section{Ayak Kempul Arang}

$\mathrm{Bk} \cdot 3.32123 \quad 6532$

$\left[\begin{array}{llllll}5522 & 5522 & 2123 & 3123 & 3521 & 2523\end{array}\right.$

$663366336 i 26 \quad i 6535321356 i$

55ii 55ii 6i26 i653 5321 2356

$\begin{array}{llllll}3366 & 3366 & 6123 & 3123 & 3521 & 2523\end{array}$

$\begin{array}{llllll}6633 & 6633 & 3123 & 3123 & 3665 & 2132:]\end{array}$

\section{Ayak Kempul Kerep}

Bk.3.3 $2123 \quad 6532$

$\left[\begin{array}{llllll}5252 & 5252 & 2123 & 3123 & 3521 & 2523\end{array}\right.$

$6363 \quad 6363 \quad 6 i 26 \quad i 653 \quad 5321 \quad 356 i$

5i5i $5 i 5 i \quad 6 i 26 \quad i 653 \quad 53212356$

$\begin{array}{llllll}3636 & 3636 & 6123 & 3123 & 3521 & 2523\end{array}$

$\begin{array}{llllll}6363 & 6363 & 3123 & 3123 & 3665 & 2132:]\end{array}$ 
Secara tekstual, dalam pakeliran wayang kulit Jawa Timuran, gendhing Ayak difungsikan sebagai pembawa berbagai macam karakter. Ayak kempul kerep dapat digunakan dalam adegan perang, karena kesan dan nuansanya yang menghentak juga cepat. Sebaliknya, gendhing Ayak kempul arang digunakan sebagai adegan lampahan, ajar kayon, serta prang alus, dengan karakter irama dan tempo yang stabil.

Sebagaimana telah disebutkan di muka, gendhing Ayak terbagi dalam empat golongan, yakni Sepuluh, Wolu, Sanga dan Serang. Dengan demikian, gendhing Ayak dalam pertunjukan wayang kulit juga berfungsi sebagai pengatur totalitas waktu sajian. Artinya, saat peralihatan pathet dan menandai pergantian waktu, gendhing Ayak akan dibunyikan sesuai dengan fungsinya. Misal, saat mendekati waktu subuh, tanpa harus dikomando seorang dalang, pengrawit dapat mulai menggunakan Ayak peralihan dari pathet Sanga ke Serang .

Gendhing Ayak selain digunakan dalam pertunjukan wayang kulit Jawa Timuran juga digunakan dalam pertunjukan lainnya, seperti ludruk dan tayuban. Alasannya, bangunan karakter dan suasana yang terdapat dalam gendhing dirasa dapat mewakili karakter dalam gerak tari tayub atau dramatika dalam pertunjukan ludruk. Walaupun demikian, intensitas penggunaan nya tidaklah sesering dalam pertunjukan wayang kulit. Lewat keterangan tersebut, setidaknya kita dapat berasumsi bahwa gendhing Ayak secara spesifik digunakan dalam pertunjukan wayang kulit, sementara bentuk pertunjukan yang lain (ludruk dan tari), dalam konteks ini, semata-mata "meminjam".

Surwedi menjelaskan bahwa Ayak dalam pertunjukan wayang kulit berperan layaknya pembuluh darah. Kehadirannya menjadi vital, sebab jika tidak ada, maka karakter wayang kulit Jawa Timuran menjadi hilang. Sama seperti rasa asin dalam soto Lamongan, jika hal tersebut hilang maka rasa soto akan hambar, dan orang dapat saja menyebutnya sebagai soto Boyolali yang cenderung manis. Oleh karena itu, Ayak ini menyangkut tentang persoalan identitas dan kedaerahan (wawancara, 2010).

Gendhing Ayak dapat pula digunakan sebagai gendhing pengganti apabila gendhing pokok tidak dikuasai oleh pengrawit. Semisal, idealnya dalam satu adegan pengrawit menggunakan gendhing Dhudha Bingung, namun karena faktor kurangnya intensitas pengetahuan dan hafalan pengrawit menjadi lupa, maka dengan segera mereka dapat menyiasatinya dengan menggunakan gendhing Ayak kempularang. 
Pertanyaannya kemudian, apakah rasa yang dibangunnya sejajar atau sama? Berdasarkan pengamatan dan wawancara penulis, memang hal tersebut tidak seratus persen sama (terkait karakter gendhing), namun karena variasi Ayak yang mencakup di semua pathet, menyebabkan lebih fleksibel, sehingga dapat menutupi dan menggantikan kesan serta karakter gendhing yang lain.

Secara anatomi kebahasaan, nama Ayak juga dimiliki oleh budaya karawitan yang lain seperti Surakarta dan Yogyakarta. Namun demikian, kesamaan nama tidak serta-merta memiliki kesamaan bentuk dan rupa. Ayak pada konteks gendhing di Surakarta dan Yogyakarta memiliki karakter dan bangunan musikal yang berbeda dibanding dengan Ayak pada karawitan Jawa Timuran. Sebagai gambaran detail, berikut diuraikan struktur musikal Ayak Wolu Jawa Timuran dengan Ayak-Ayakan Slendro Manyura gaya Surakarta.

Ayak Wolu, Pancer 5, Laras Slendro Jawa Timuran

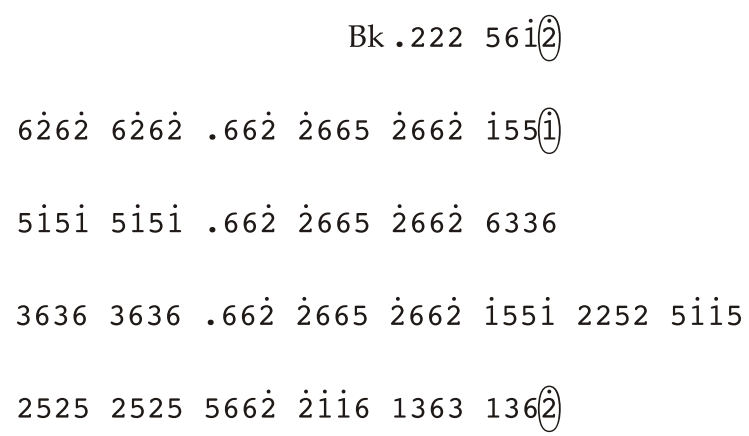

\section{Ayak-Ayakan Slendro Manyura gaya Surakarta}

Bk Kendhang:2

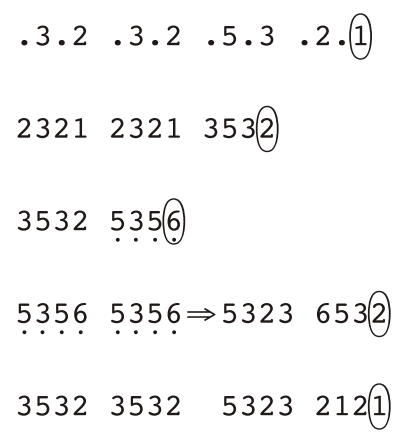

Contoh di atas adalah salah satu perbedaan bentuk gendhing Ayak dalam dua budaya musik. Meskipun memiliki kesamaan nama, namun mereka memiliki struktur pemainan musikal yang berbeda. Tentu saja, perbedaan yang ada tidak dimaksudkan untuk memberi penilaian mana yang baik dan buruk. Akan tetapi penulis berusaha menyandingkan untuk memberi gambaran dan pemahaman yang lebih detail dan jelas. 
Dengan demikian, penciptaan suatu gendhing didasarkan pada konteks ruang dan waktu. Ruang merupakan latar belakang di mana gendhing itu digunakan, sedangkan waktu berkait dengan tujuan untuk apa gendhing itu diciptakan. Oleh karena itu, Ayak dalam karawitan Jawa Timuran akan dimaknai secara berbeda pada konstruksi kebudayaan musik di daerah lain. Hal ini bergantung pada proses dan latar belakang sebagaimana tersebut di atas.

\section{Jenis-Jenis Gendhing Ayak Wolu}

Dalam wilayah pathet Wolu, Gending Ayak Wolu memiliki jenis-jenis pola permainan dan adegan wayang kulit yang disajikan. Ada Ayak Mlaku, Ayak Dolanan, Ayak Banyumili, Ayak Pancer Dan Ayak Gethekan. Jenis-jenis Ayak tersebut bisa dikatakan memiliki peran khusus dalam setiap adegan. Kekhususan Ayak tersebut dikarenakan dalam permainannya memang digarap dengan sesuai karakter adegan wayang. Berikut notasi salah satu jenis Gending Ayak Mlaku laras Slendro pathet Wolu.

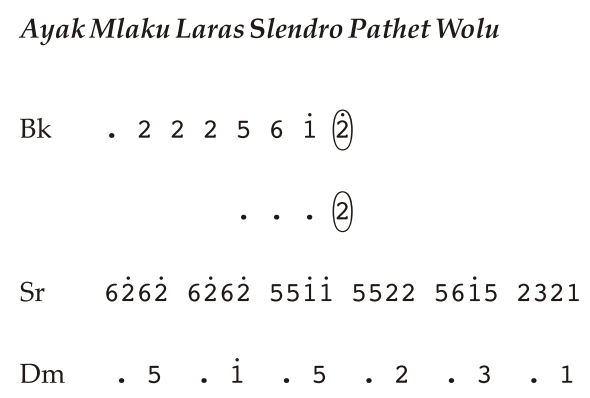

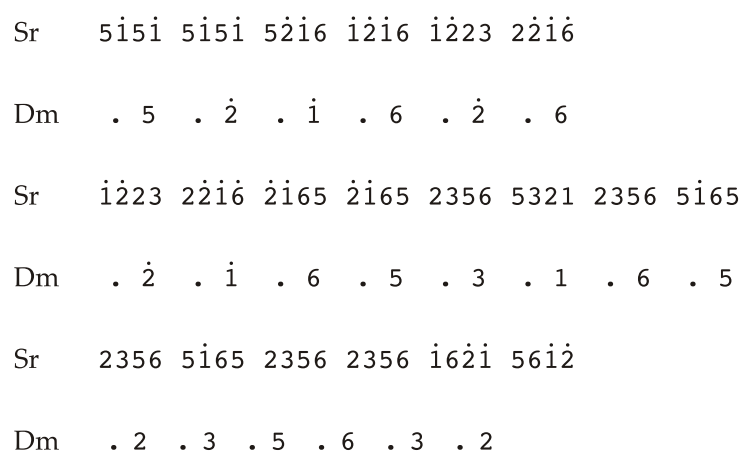

Di atas merupakan notasi Ayak mlaku, yang dimainkan pada instrumen saron dan demung. Mlaku yang dimaksud di atas yaitu lebih ditekankan pada adegan wayang kulit di mana salah satu tokoh wayang yang berkarakter gagah sedang melakukan perjalanan dari daerah satu ke daerah lain. Dalam segi ricikan, instrumen saron menggunakan balungan mlaku .

Berikutnya adalah gendhing Ayak Banyumili laras Slendro pathet Wolu. Penamaan Banyumili disini sebenarnya bukan mengacu pada adegan, karena adegan dan suasananya hampir sama seperti Ayak mlaku, sedangkan Banyumili lebih ditekankan pada pola permainan saron yang mengalir dari atas ke bawah pada wilayah Saron. Jenis Ayak Banyumili ini berperan pada adegan-adegan yang menegangkan, seperti peperangan. Gendhing ini dimainkan untuk membangun pocapan (pembicaraan wayang) sebelum melakukan perang, atau bisa pada adegan sereng (tergesa-gesa) pada tokoh yang sedang penasaran untuk mengetahui sesuatu. 


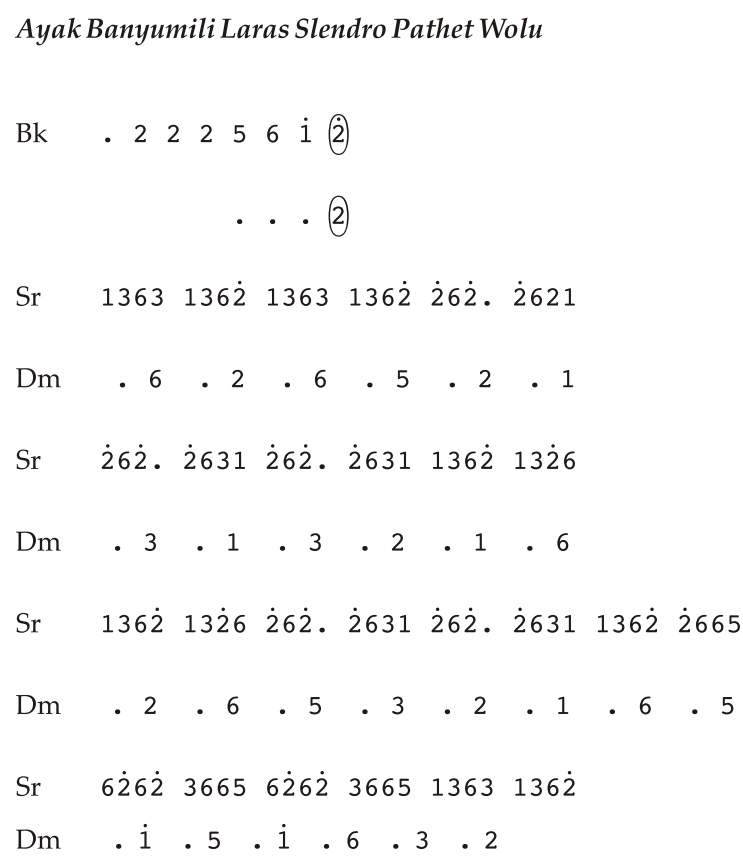

Berikutnya, gendhing Ayak Pancer memiliki beberapa jenis pula, seperti Pancer 5, Pancer 2, Pancer 6, Pancer 1, dan Pancer 3. Ayak Pancer dapat diidentifikasi sebagai Ayak melalui tabuhan kenong pertama, ketiga, dan kelima. Setelah itu nada pada gatra ketiga dan keempat menjadi acuan untuk gatra kesembilan, kesepuluh, kelimabelas, dan keenambelas pada sabetan saron. Dalam satuan wilayah pathet Wolu, Ayak Pancer juga memiliki urutan seperti diatas.

Dalam pathet Wolu, nada yang dibangun dalam permainan gendhing Ayak Pancer 5 dikhususkan pada adegan-adegan wayang perang kupu tarung atau perang alus. Berikut adalah notasinya.

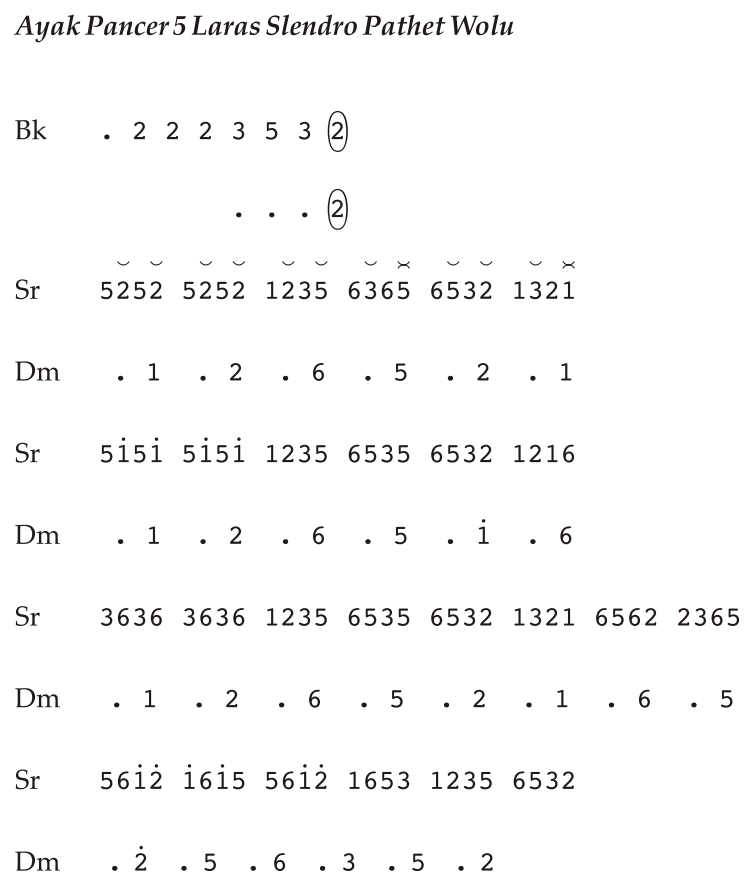

Berikut adalah notasi Pancer 2 gendhing Ayak Wolu, dengan identifikasi sama seperti Pancer 5. Dalam Ayak Pancer 2, adegan-adegan wayang yang sering dimainkan yaitu adegan perang dhugangan antara tokoh raksasa lawan raksasa.

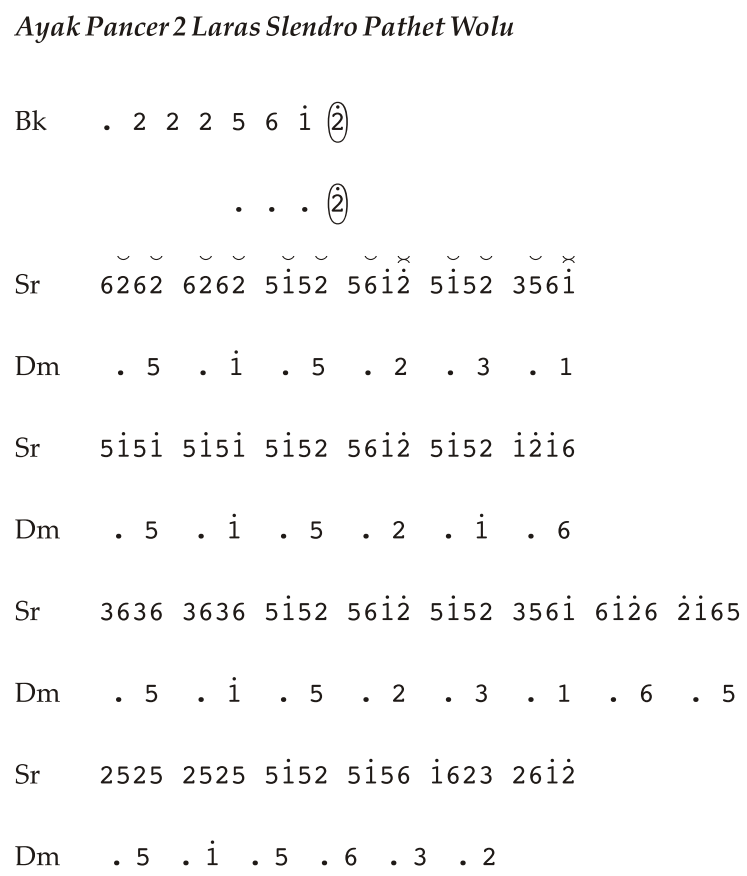


Selanjutnya adalah Pancer 6 dalam pathet Wolu. Identifikasinya sama dengan Pancer 5 dan 2, namun untuk adegan yang berbeda, yaitu pada adegan panakawan atau tokoh wayang rakyat jelata. Di sini tidak ada perang fisik, namun hanya adu mulut dengan suasana lucu.

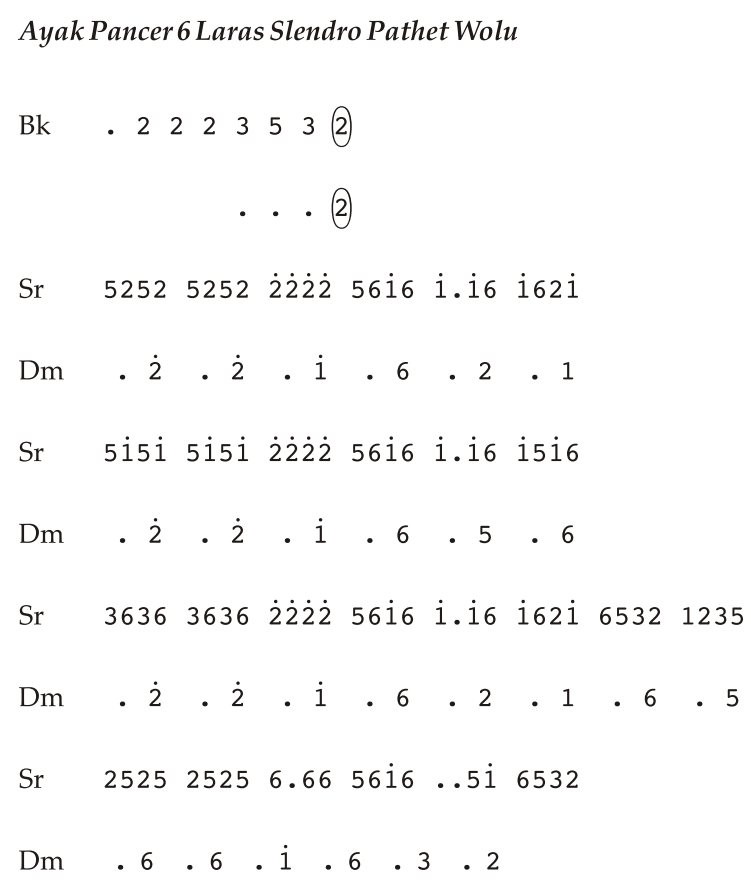

Berikutnya adalah pancer 1 dalam pathet Wolu. Identifikasinya tetap sama dengan pancer yang lain. Pancer 1 sebenarnya digunakan untuk transisi menuju ke pancer 3. Adegannya tidak memiliki sesuatu hal yang khusus, namun sering dimainkan setelah perang. Suasana yang dibangun tergantung dengan suasana perang sebelumnya.

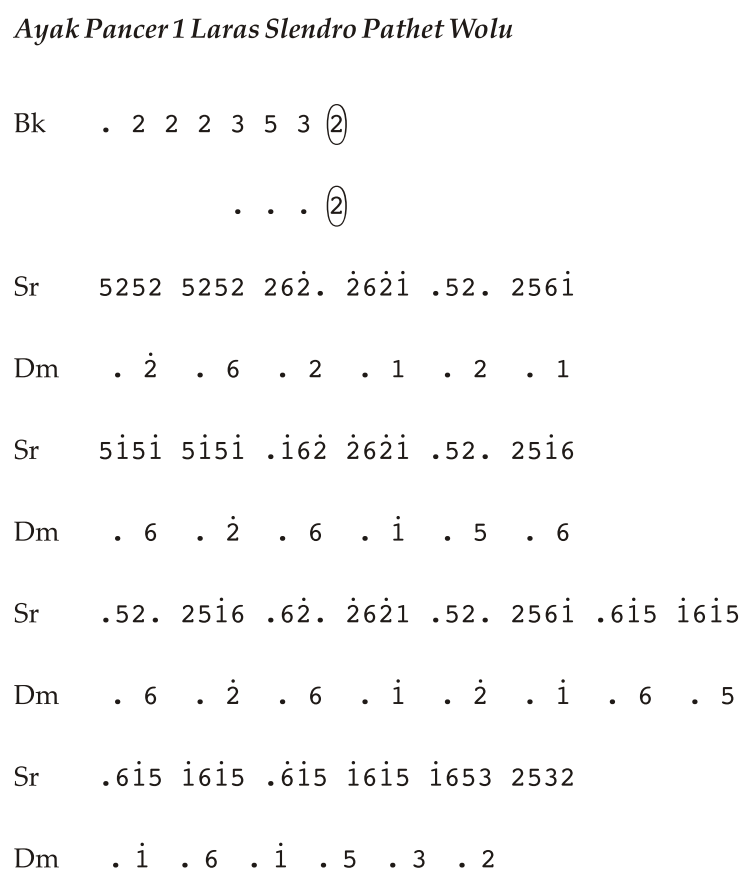

Selanjutnya, Pancer 3 dalam pathet Wolu. Identifikasinya tetap sama dengan pancer yang lainnya. Pancer 3 berfungsi sebagai transisi antara pathet Wolu menuju pathet Sanga. Apabila seorang dalang menghendaki Ayak Pancer 3, seorang dalang akan memberi kombangan nada 3 . Adegan disini lebih pada adegan jejeran yang menunjukkan sebuah hasil peperangan.

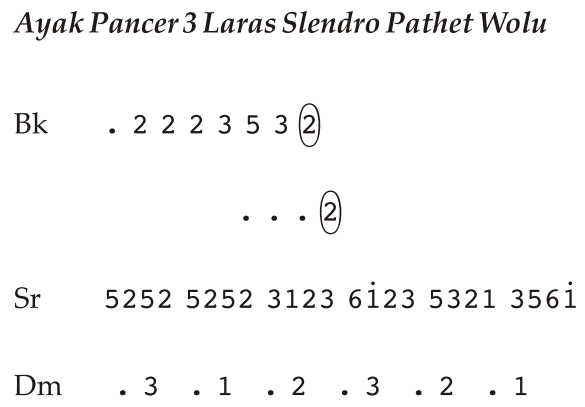


Sr $\quad$ 5i5i 5 i5i $31236 i 2323212356$

$\mathrm{Dm} \cdot 3 \cdot 1 \cdot 2 \cdot 3 \cdot 5 \cdot 6$

Sr $\quad 3636363631236 i 232321356 \dot{1} 65 \dot{2} \dot{2} \dot{6} 65$

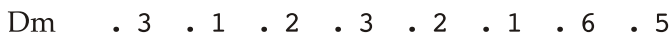

Sr $\quad 25252525 \dot{26} \dot{i} 6 \dot{123} 53213532$

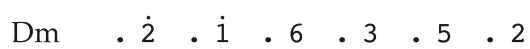

Setelah jenis-jenis pancer, berikutnya adalah gendhing Ayak Gethekan yang biasanya digunakan setelah adegan jejer pertama di kerajaan. Tidak seperti pada Ayak pancer atau Ayak yang lain, Ayak gethekan balungannya ada pada instrumen demung dan tidak terpaku pada melodi saron.

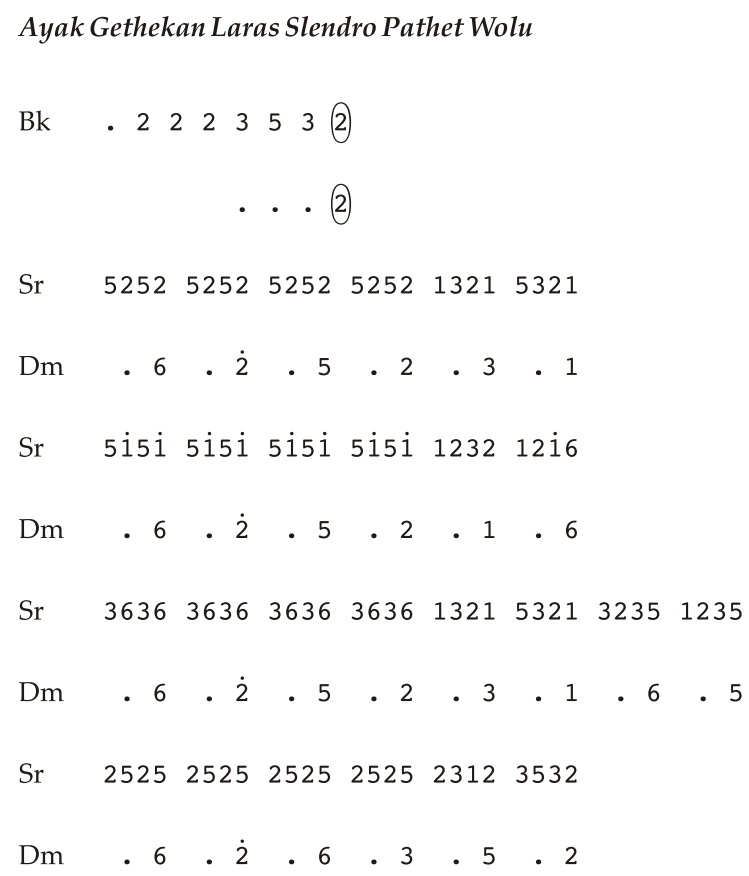

Gendhing Ayak Dolanan biasanya digunakan untuk iringan keluarnya para panakawan. Istilah dolanan sebenarnya diambil dari permainan instrumen saron saja, yang mengadopsi dari gendhinggendhing dolanan Jawa Timuran. Permainannya menggunakan teknik imbal saron seperti dalam Ayak pancer. Perbedaannya terletak pada melodi yang dibuat oleh instrumen saron memiliki suasana lucu atau gembira.

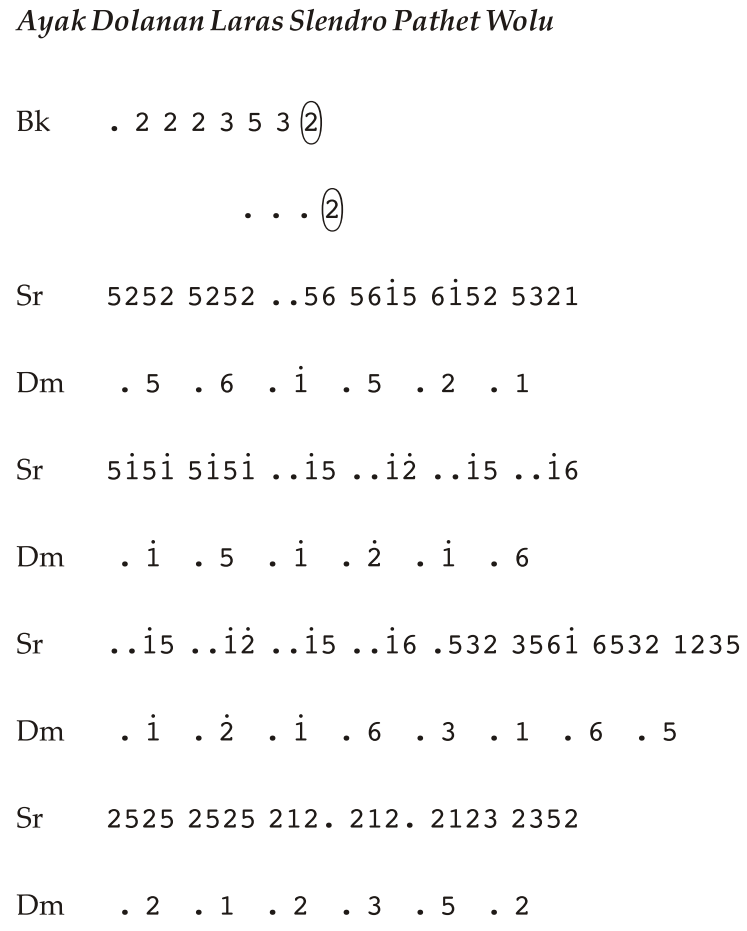

\section{Gendhing Ayak Wolu dalam Pakeliran Ki Surwedi}

Keberadaan gendhing Ayak dalam sajian pakeliran Jawa Timuran bisa dikatakan sangat dominan, karena dalam 
setiap babak yang menjadi struktur sajian pakeliran yang ada, gendhing Ayak selalu hadir dan dimainkan. Akan tetapi, agar tema wilayah bahasan dan kajian tidak terlalu luas, penulis merasa perlu mempersempit tema kajian yakni pada bentuk Ayak Wolu. Pemilihan Ayak Wolu lebih didasarkan pada persoalan musikalitas, mengingat Ayak jenis ini memiliki variasi garap yang paling banyak, serta dihadirkan dalam totalitas waktu yang paling panjang dalam sebuah pertunjukan wayang. Tentu saja, diharapkan dengan mengambil subjek pada Ayak Wolu dapat mewakili orientasi musikal pada Ayak-Ayak dalam pathet yang lain.

Pada prinsipnya, istilah gendhing Ayak Wolu hanya digunakan dalam karawitan Jawa Timuran. Gendhing Ayak yang mendapat imbuhan kata wolu merupakan salah satu tindakan pelaku seni untuk lebih mudah mengkodifikasi gendhing pakeliran, yang memang disesuaikan dengan kodifikasi pakeliran wayang kulit. Dengan demikian, gendhing yang dihadirkan dalan sajian wayang kulit Jawa Timuran secara otomatis juga memiliki kodifikasi yang sama dengan pakelirannya, yakni berdasarkan pathet.

Gendhing pathet Wolu biasa digunakan untuk sajian gendhing-gendhing sore atau Giro, dan dalam pakeliran dimulai setelah ada tamu dalam adegan jejer sepisan, yakni antara pukul 23.00 hingga 02.00.
Penggunaan pathet dalam pakeliran wayang Jawa Timuran memang cenderung lebih lama saat menggunakan pathet Wolu. Hal tersebut terjadi karena pembagian adegan dalam pathet Wolu cenderung lebih panjang dari yang lain, yaitu dari adegan jejer sepisanan hingga adegan gara-gara, bahkan sampai pada perang alusan (perang begal) dan sajian gendhing-gendhing dolanan pada adegan gara-gara masih berkisar pada pathet Wolu.

Gendhing Ayak Wolu yang mendapat imbuhan kata pathet memiliki arti bahwa gendhing Ayak tersebut memiliki fungsi untuk mendukung sajiannya pada wilayah pathet Wolu dalam pakeliran. Karena dalam adegan wilayah pathet wolu memang beraneka macam, banyak pula gendhing yang disajikan sesuai dengan lakon yang dibawakan dalam pakeliran semalam suntuk. Salah satu gendhing tersebut adalah gendhing Ayak yang paling banyak istilahnya. Istilah-istilah dalam sajian tersebut sebenarnya berguna untuk memudahkan atau mengingat gendhing Ayak mana yang akan dipakai untuk mendukung adegan.

Pemaknaan terhadap gendhing Ayak Wolu dalam sajian pakeliran wayang kulit Jawa Timuran Ki Surwedi tentu tidak akan lepas dari fungsi-fungsinya, seperti yang telah diungkapkan oleh Alan P. Merriam bahwa makna musik tidak hanya 
menyangkut fakta-fakta deskriptif mengenai musik. Tetapi lebih dari itu, kita ingin mengetahui pula efek/dampak musik terhadap manusia, dan bagaimana cara musik menghasilkan efek tersebut. Dari beberapa teori fungsi yang disusun oleh Merriam, beberapa di antaranya adalah fungsi hiburan, fungsi pengungkapan emosional, serta fungsi pengintegrasian masyarakat.

Gendhing Ayak Wolu pada umumnya menjadi bagian dari repertoar pertunjukan wayang kulit Jawa Timuran, tetapi kedudukan gendhing Ayak Wolu dalam pakeliran Ki Surwedi sudah menjadi kesatuan yang utuh. Pertunjukan wayang kulit merupakan wahana tontonan dan tuntunan sebagai sarana hiburan dalam masyarakat pendukungnya. Tuntutan utama di sini yaitu ditekankan pada daya kreatif $\mathrm{Ki}$ Surwedi dalam mengolah kembali aspek musikalitas gendhing Ayak Wolu tanpa harus meninggalkan esensi dari pertunjukan, sehingga pada akhirnya pertunjukan wayangnya menjadi tontonan yang menarik serta tidak monoton.

Bila dicermati kembali, gendhing pakeliran memang difungsikan untuk membangun dramatisasi adegan yang harus sesuai dengan karakter tokoh wayang. Di sinilah letak fungsi pengungkapan emosional tersebut. Meskipun dalam pertunjukan wayang kulit, alur cerita sudah tersusun, namun sebagai penguat suasana dalam adegan, gendhinglah yang mempertebal karakter suasana adegan tersebut. Gendhing Ayak Wolu dapat dikatakan sebagai salah satu gendhing yang banyak dimainkan dalam durasi yang panjang. Dalam wilayah pathet Wolu, pembagian waktu pertunjukan wayang kulit Jawa Timuran bisa mencapai presentase $60 \%$ sendiri. Bila dijabarkan, berikut adalah keterkaitan emosional gendhing Ayak Wolu dalam adegan pathet Wolu.

- Dalam pathet Wolu adegan pertama, pasti ada adegan jejer pertama yang suasanya tenang dan agung, karena pada jejer pertama ini digambarkan situasi kedathon atau salah satu ruang pertemuan seorang raja. Adegan ini biasanya berkembang sesuai lakon wayang, namun perkembanganya bisa jadi gaduh, tenang, sedih, gembira, dan banyak yang lain. Gendhing Ayak Wolu yang digunakan untuk membangun suasana pakeliran adalah Ayak Wolu Kempul Kerep atau Ayak Wolu Gethekan dengan beraneka macam variasi yang dikembangkan lewat kreativitas seniman.

- Adegan paseban jáwi atau adegan di luar keraton merupakan transisi setelah adegan kedhaton. Suasananya bergantung pada adegan pertama. Bila 
dalam keraton suasananya gaduh, maka adegan kedua juga mulai gaduh. Sebaliknya jika adegan pertama tenang, maka adengan kedua juga tenang. Pada umumnya perkembangan adegan kedua ini lebih pada suasana tegang, dan sering terjadi peperangan. Gendhing Ayak Wolu yang sering digunakan yaitu gendhing Ayak Banyumili dan gendhing Ayak Gethekan.

- Adegan kedathonan kedua menjadi pertanda adegan paseban jáwi telah selesai. Adegan kedathonan yang kedua suasananya sama-sama tenang dan agung, namun terkadang tegang dikarenakan ada pesan dari adegan paseban jáwi, sehingga suasananya bergantung pada pesan yang dibawa. Pesan tersebut bisa baik atau buruk. Berakhirnya adegan kedhaton kedua ditandai dengan seorang ratu yang melakukan ritual doa. Iringan yang digunakan untuk mengiringi adegan ini adalah gendhing Ayak Wolu Gedhog Rancak.

- Prang sepisan suasananya antara tegang dan bimbang, karena suasana tersebut terbangun dari sebuah hasil keputusan raja di adegan kedathon kedua. Gendhing Ayak Wolu yang digunakan yaitu Ayak Wolu Pancer 5 dan Ayak Wolu Pancer 2. Di sini, seorang seniman yang memainkan instrumen saron memperhatikan tokoh wayang yang dimainkan oleh dalang. Apabila wayang yang dimainkan dalang memiliki tubuh yang sama kecil, seorang dalang menghendaki Ayak Wolu Pancer 5 untuk adegan perang alusan atau Kupu Tarung. Sebaliknya, apabila dalang mengeluarkan tokoh yang memiliki tubuh yang sama besar, berarti ia menghendaki perang dhugangan dengan iringan Ayak Wolu Pancer 2.

- Adegan Gara-Gara atau adegan jejer ketiga tak ada kaitannya dengan adeganadegan sebelumnya. Adegan ini bisa dikatakan berada di wilayah yang berbeda, serta biasanya mencari solusi bagi suatu masalah yang dipaparkan pada adegan sebelumnya. Adegan jejer ketiga ini adalah transisi dari pathet Wolu menuju pathet Sanga. Sebelum masuk dalam adegan jejer ketiga yang mulanya menggunakan iringan Gending Ayak Wolu Pancer 5 atau Ayak Wolu Pancer 2, berubah menjadi Gending Ayak Wolu Pancer 3. Perubahan iringan ini ditandai dengan kombangan dari seorang dalang. Dalam adegan Gara-Gara atau jejer ketiga ini, tokoh yang keluar adalah panakawan Jawa Timuran. Suasana yang dibangun pada adegan jejer ketiga ini lebih ke suasana hiburan. 
Gendhing Ayak Wolu merupakan salah satu identitas dalam pakeliran wayang kulit Jawa Timuran. Kedudukan gendhing Ayak Wolu dalam pakeliran wayng kulit Jawa Timuran memiliki posisi yang sangat penting. Hal ini dibuktikan, bahwa dalam sistem sajian gendhing dalam pertunjukan wayang kulit Jawa Timuran, gendhing ini memiliki porsi "lebih" dalam peranannya sebagai gendhing pakeliran. Selain itu, masyarakat pendukungnya pun juga banyak mengenal gendhing Ayak sebagai gendhing pakeliran, meskipun dalam sajian wayang juga terdapat gendhing-gendhing lain yang baku.

Kiranya beberapa fungsi di atas sudah sangat cukup memperjelas kedudukan gendhing Ayak Wolu dalam pakeliran wayang kulit Jawa Timuran Ki Surwedi, sebagai sarana mutlak yang membentuk identitas pakeliran wayang kulit Jawa Timuran.

\section{Kesimpulan}

Gendhing Ayak Wolu merupakan suatu bentuk iringan pakeliran wayang kulit purwa Jawa Timuran yang tidak dimilki oleh iringan wayang kulit manapun. Dari berbagai jenis iringan pakeliran Jawa Timuran, gendhing Ayak Wolu juga merupakan iringan yang baku serta harus dilakukan dalam pertunjukan wayang Jawa Timuran, sekaligus menjadi salah satu ciri khas iringan pakeliran Jawa Timuran. Masyarakat pendukung pedalangan Gaya Jawa Timuran selalu

melestarikan gendhing Ayak Wolu karena keberadaannya sangat dibutuhkan dalam iringan pakeliran. Pertunjukan pakeliran semalam suntuk tidak terlepas dari gendhing Ayak Wolu karena perannya yang sangat penting, di antaranya adalah untuk mendukung suasana pakeliran seutuhnya.

Seorang dalang dan pengrawit juga diharapkan memahami arti dan fungsi gendhing Ayak Wolu. Walaupun gendhing Ayak Wolu hanya sebatas dominan pada instrumen saron, akan tetapi mempunyai tingkat kemapanan tersendiri. Hal tersebut secara tidak langsung sudah kita rasakan pada waktu mendengarkan serta melihat pertunjukan wayang kulit Jawa Timuran.

$$
\text { Gendhing Ayak Wolu juga }
$$
merupakan salah satu bentuk karya seni dari nenek moyang terdahulu yang sudah diwariskan turun-temurun kepada generasi penerus. Oleh sebab itu, sudah menjadi kewajiban kita bersama untuk menjaga dan melestarikannya agar terhindar dari kepunahan.

Di dalam sajian Gending Ayak Wolu memang ada hal-hal yang tidak sama penyajiannya, terutama teknik menabuh beberapa instrumen, seperti slenthem, misalnya. Tetapi hal itu terjadi bukan karena disengaja melainkan keterbatasan sumber 
daya manusia yang kurang memadai, di mana kita perlu mengkaji kembali karena gendhing Ayak Wolu terpola dengan apa yang diterima saat menirukan generasi yang mendahuluinya.

\section{Daftar Pustaka}

Hajizar. 1989. "Konsep sebagai Sumber Analisis," Makalah Penataran Peneliti Muda ASKI Padang Panjang. Padang Panjang: ASKI.

Kayam, Umar. 2001. Kelir Tanpa Batas. Yogyakarta: Gama Media.

Merriam, Alan P. 1964. The Anthropology of Music. Illinois: Northwestern University Press.

Munardi, AM, dkk. 1983. Pengetahuan Karawitan Jawa Timuran. Jakarta: Departemen Pendidikan dan Kebudayaan.

Prabawanti, Wingit. 1983. Pengetahuan Karawitan Daerah Surakarta. Jakarta: Departemen Pendidikan dan Kebudayaan.

Tasman. 1981. Notasi Gendhing Mojokerto Suroboyo. Surabaya: Kantor Wilayah Departemen Pendidikan dan Kebudayaan Propinsi Jawa Timur.

Waridi. 2000. "Garap dalam Karawitan Tradisi: Konsep dan Realitas Praktik". Makalah Seminar Karawitan Nasional. Surakarta: STSI Surakarta.

\section{Narasumber}

a. Bambang Sukmo Pribadi; seniman, kreator musik, pengamat karawitan Jawa Timuran, dan guru di SMKI Surabaya.

b. Sulaiman (Alm.); dalang wayang kulit gagrag Jawa Timuran.

c. Supriono; seniman, dalang, penyiar di RRI Surabaya, dan guru di SMKI Surabaya.

d. Surwedi; dalang wayang kulit gagrag Jawa Timuran. 